\title{
THE PRAGMATICS OF “UNRULY” DATIVE ABSOLUTES IN EARLY SLAVIC
}

\author{
DANIEL E. COLLINS \\ The Ohio State University
}

\section{A B S TRACT}

This chapter examines some uses of the dative absolute in Old Church Slavonic and in early recensional Slavonic texts that depart from notions of how IndoEuropean absolute constructions should behave, either because they have subjects coreferential with the (putative) main-clause subjects or because they function as if they were main clauses in their own right. Such "noncanonical" absolutes have generally been written off as mechanistic translations or as mistakes by scribes who did not understand the proper uses of the construction. In reality, the problem is not with literalistic translators or incompetent scribes but with the definition of the construction itself; it is quite possible to redefine the Early Slavic dative absolute in a way that accounts for the supposedly deviant cases. While the absolute is generally dependent semantically on an adjacent unit of discourse, it should not always be regarded as subordinated syntactically. There are good grounds for viewing some absolutes not as dependent clauses but as independent sentences whose collateral character is an issue not of syntax but of the pragmatics of discourse.

\section{[1] INTRODUCTION}

In previous literature, the Early Slavic dative absolute has generally been viewed as a subordinate clause dependent on a matrix clause, like the converbs (adverbial participles) of the modern Slavic languages. ${ }^{1}$ As defined in an authoritative handbook of Old Church Slavonic, the dative absolute is "a participial subordinate clause expressing various types of attendant circumstance" (Lunt 2001, 149). This is in accordance with a typologically-oriented definition of absolute constructions in European languages as clause-linkage in which a non-finite clause is "linked and subordinated to a main clause," "in construction with the main clause or the V[erb] P[hrase] thereof" (König \& van der Auwera 1990, 337). A more detailed description of the Early Slavic dative absolute specifies the nature of the subordinative relation as well as syntactic constraints on the construction: "the participial expression of subordination of one clause to another in appositive or adverbial function,

[1] A clause is understood here as “any syntagm containing one predication” (Lehmann 1988, 182). On converbs in Russian, see Weiss (1995). On converbs in other European languages, including Slavic languages, see Nedjalkov (1998). 
where the subjects of the two clauses differ [emphasis in the original]" (Corin 1995, 266). ${ }^{2}$ Still other studies of the construction specify that the absolute participial clause is "embedded" in the matrix clause. ${ }^{3}$ Dative absolutes have often been viewed as equivalent to finite adverbial clauses subordinated with conjunctions like egda 'when'-for example, "Dem Casus absolutus (Cas. abs.) entspricht ein mit Konjunktion eingeleiterer Nebensatz" (Reiter 1997, 243). However, it is not always clear whether such comparisons are meant to imply that absolutes are likewise syntactically dependent, or simply that they can convey the same kind of dependent semantic relations as finite adverbial clauses with explicit subordinators. ${ }^{4}$

Undoubtedly these definitions of the dative absolute adequately describe the majority of the tokens in Early Slavic texts, provided one assumes a priori that all participial clauses are subordinated. Nevertheless, there is a significant residue of absolutes that do not follow the given rules, because their subjects are coreferential with the subjects of their putative main clauses, because they seem not to have main clauses to which they can be subordinated, or in general because they occur where standard descriptions of old Church Slavonic syntax would predict finite verbs (e.g., in coordination with finite clauses, or after explicitly subordinating conjunctions or subjunctions like egda). In the literature, such misfits are generally treated as irregularities; some scholars even write them off as mistakes by inept, slavish translators or by incompetent scribes who did not understand the proper use of a bookish, alien, or moribund construction. Undoubtedly the Early Slavic translators and scribes did make mistakes on occasion (like modern writers without careful editing). However, before we dismiss a sizable number of examples of a widespread construction-examples that make sense in their context-we should re-examine the rules or constraints that they supposedly flout.

In the following sections, I will re-examine some examples of the Early Slavic dative absolute that violate the standard definition of the construction. I will show that, if we jettison certain pre-conceived notions of what an absolute should be, these supposedly irregular cases actually turn out to be quite regular. The real problem is not that the absolutes are unruly but that the rules that have been formulated are too narrow. To make the definition of the dative absolute more inclusive, it will be necessary to decouple the issues of semantic dependency and syntactic subordi-

[2] See further Corin $(1995,259-60,261)$. On the absolute as a subordinate clause, see, e.g., Večerka (1961, 49), Večerka (1996, 186: "zweitrangigen Prädikate"), Berent (1973, 147, "syntactic nonindependence"), Gebert (1987, 565), Minčeva (1991, 449), Reiter (1997, 243), Leafgren (2002, 147).

[3] See Mrazek (1963, 260: "complex nominal condensators, i.e., devices for the compressed transmission of a more complicated idea in the frame of a single sentence"), Berent (1973, 151, "superficially embedded", "nominal subordinate clauses"), see also Berent $(1975,11)$.

[4] For instance, after providing several instances of the construction, Schmalstieg $(1982,186)$ states, "in all of the examples given above the action of the expression in the dative absolute is subordinate to the action of the main clause." Judging from the references to "the action," this is an observation about the semantic relation between the two propositions; judging from the the reference to "the main clause," it is an observation about their syntactic relation. 
nation (hypotaxis). As I will argue, the putative syntactic constraints on dative absolutes are not definitional for the construction; they are simply tendencies based on patterns of discourse cohesion and applicable mostly to narrative. Scholars have mistaken them for rules under the influence of absolute constructions elsewhere in Indo-European and/or prescriptive notions derived from the behavior of participial clauses in modern languages.

In section [2], I will define the term Early Slavic, justify the use of translations from Greek as representatives of Early Slavic writing, and explain why the origin of the dative absolute is irrelevant for the subsequent discussion. Following these preliminaries, in section [3], I will give a brief overview of dative absolutes that are "unruly" in having subjects coreferential to those of adjacent, putatively governing clauses. In section [4], I will provide evidence that some "unruly" dative absolutes function as independent rather than subordinate clauses; I will also look at some cases of nominative absolutes (section [4.5]). In section [5], I will further explore the significance of decoupling the secondary semantic status of dative absolutes from the notion of syntactic subordination. I will conclude by offering a preliminary redefinition of the dative absolute construction and the meaning of the dative case that it reflects (section [6]).

\section{[2] METHODOLOGICAL PRELIMINARIES}

Three issues need to be discussed at the outset. The first is the definition of Early Slavic. I use this term as a shorthand for writings in Old Church Slavonic and its recensions that were composed in the first hundred or so years of Slavic literacy, either by SS. Cyril and Methodius and their disciples in the mid- to late ninth century or by bookmen of the First Bulgarian Kingdom in the tenth and early eleventh centuries. Given the prolonged tradition of textual transmission in Slavia Orthodoxa, such compositions can appear in manuscripts from the late Middle Ages or beyond; however, I will draw examples mainly from manuscripts that date from the earliest period of attestation (late tenth to twelfth centuries). Restricting the material to relatively early manuscripts does not, of course, rule out the possibility that changes were made in the copying process; it is simply a way of imposing limits on a potentially enormous database.

The second issue is the fact that much of the data I will use comes from translations rather than original Early Slavic compositions. This is inevitable, given the nature of the Church Slavonic corpus. It is important to keep in mind that, after the initial translation was made, most of the users of the text would not know or care whether it was translated or not; it was simply a Church Slavonic text conveying Christian teachings. ${ }^{5}$ In its intended sphere of usage, the translation functioned entirely independently of its source text; it was no different for the audi-

[5] I owe this insight to Roland Marti. 
ence-readers, hearers, and copyists-than a text written by a Slavic author, which would undoubtedly imitate the language of authoritative translations. For these users, the fact that many dative absolutes happen to translate Greek genitive absolutes would have been as irrelevant as the fact that many nominative participles translate Greek nominative participles; they would not have rejected either construction as foreign (even if they were uncommon or absent in their spoken language). For this reason, I would argue, coherent translated passages can and must serve as legitimate input for historical-pragmatic research on Early Slavic. Undoubtedly, constructions that are etymological Hellenisms do occur in Early Slavic texts; however, rather than being dismissed a priori, they should be viewed as part of the model written language for the intended users of the texts. ${ }^{6}$

The third issue is the ultimate origin of the dative absolute construction. This is as irrelevant to a pragmatic discussion as the issue of translation. There has, of course, been a long controversy over whether the dative absolute was inherited-either as a continuation of a Proto-Indo-European construction or as an einzelsprachlich development-or a calque of the Greek genitive absolute. ${ }^{7}$ (There is also a compromise position that it was an "immanent" structure activated in Slavic under Greek influence. ${ }^{8}$ ) In my view, the preponderence of evidence indicates that it was inherited, like the absolute constructions in Sanskrit, Avestan, Baltic, Germanic, ${ }^{9}$ Italic, Greek, Armenian, Tocharian, and possibly also Hittite, but its origin has no bearing on my present purpose, which is to account for seemingly problematic aspects of its behavior in actual discourse. ${ }^{10}$ Even if the dative absolute were non-Slavic in origin, that would not obviate the need to account for its synchronic usage, as if it were an unassimilated barbarism or occasionalism. In fact, if the dative absolute was a contact-influenced innovation, as some scholars have

[6] In her presentation "The Sacral Stamp of Greek" at the International Workshop on Indo-European Syntax and Pragmatics, Bridget Drinka aptly characterized similar Hellenisms in Gothic as "devotional" rather than "slavish." She noted that, in the new literacies that arose as part of Christianization, reverence for the Scriptures led to the imitation and assimilation even of non-native syntactic features as "emblems of membership in the Christian community."

[7] See, inter alia, Andersen (1970), Berent (1973, 148-150), Coleman (1989, 353-60), Corin (1995, 255-56), Grković-Major $(2001,17)$. As Ramat $(1994,261)$ notes, "Both infinitives and absolute constructions are consistent with the old IE type and may therefore be typologically ascribed to the parent language."

[8] This is the position of Večerka $(1997,375)$, who argues that the dative absolute, as an adjunct participial construction, was neither fully native or fully artificial but rather a contact-influenced innovation on the basis of existing conjunct participles: "Although their domestic roots cannot be excluded (e.g. in connected constructions, as in reče imŭ priš́dŭšiimŭ), according to which the secondary adverbial meaning of the dative construction ("he said to them to-having-come" $\rightarrow$ "he said when they came") was generalized and transferred to "disconnected" constructions too, the spread of absolute constructions in OCS was obviously called forth by the aim to make OCS translations communicatively adequate to the Greek originals, where absolute constructions were frequent, on the basis of "pseudo-identification" of the OCS dative with the Greek genitive."

[9] The origin of the Gothic absolute has also been controversial. See Dewey \& Syed (2009) for evidence that it was not borrowed and that case variation in the construction was systematic and motivated.

[10] See Hristova (2004) for a detailed discussion of the controversy and new evidence in favor of the position that the dative absolute was an inherited construction. 
claimed, it was spectacularly successful in ways most other features of borrowed syntax (e.g., accusativus cum infinitivo constructions) were not; it quickly became a pervasive characteristic of learned writing throughout medieval Slavia Orthodoxa, and its variation was subject to rules, in the manner of native constructions.

\section{[3] SWITCH-REFERENCE VS. CO-REFERENCE IN THE DATIVE ABSOLUte}

It has sometimes been claimed that absolute clauses should exhibit switch-reference, i.e., should not co-refer with elements in the clauses on which they are semantically dependent (which have been considered, in syntactic terms, their "main" or "matrix" clauses). For example, in a cross-linguistic study, König \& van der Auwera $(1990,337)$ define the absolute construction as "a reduced clause without a finite verb" that is "linked and subordinated" to a main clause, with which it does not share any arguments ("absolute deranking," ibid., 338). However, a total ban on coreference fails to hold water not only in Early Slavic but also in other Indo-European languages. Indeed, König \& van der Auwera $(1990,340)$ also observe that absolute constructions generally require some kind of connection with their main clauses; in English, for example, absolutes with tenuous links to their main clauses tend to be less acceptable than those with clear connections (see also Berent 1975, 20).

A weaker version of the co-reference constraint holds that the subject of the absolute, at least, must refer to an entity different from the main-clause subject; however, even this does not pass muster in Early Slavic or, indeed, for some IndoEuropean languages of more ancient attestation. ${ }^{11}$ To be sure, the majority of dative absolutes in Early Slavic do in fact exhibit the switch-reference predicted by the supposed constraint; subject co-reference more typically belongs to the functional sphere of the semantically similar free adjunct, i.e., agreeing participle. For this reason, scholars have approached absolutes and free adjunct participles as if, in proper usage, they should occur in a clear-cut complementary distribution: "Exceptions to the subject non-identity condition imply neutralization of the sole syntactic feature which differentiates the function of absolute and non-absolute participial constructions" (Corin 1995, 268; cf. also Večerka 1961, 49; idem 1996, 190). Violations of this supposedly "'cardinal"' constraint (Corin 1995, 266) have been viewed either as outright mistakes or as reflections of the "decadence" of a moribund construction. Thus Bauer $(2000,280)$ treats "the lack of co-reference with the subject of the finite verb" as evidence that the Slavic dative absolute was inherited from Proto-Indo-European rather than borrowed; she further asserts that "only in later instances does co-reference occur." This supposed break-down of the dative absolute fits well into Bauer's scheme of Indo-European moving from active typology, where agreement relations dominate, to nominative typology, where transitivity relations dominate (Bauer 2000, 335, 337).

[11] On Koine Greek, see Whaley (1990, 461-464). On Latin, see Hoff (1989), Ramat (1994, 263), Sluiter (2000, 391, note 17). There are also co-referential dative absolutes in Baltic (Stanislav 1933-1934, 13). 


\begin{tabular}{lccc}
\hline & Absolutes & Coreferentials & \% Total \\
\hline OCS Gospels + Suprasliensis & 1186 & $69-72$ & $5.8-6.1 \%$ \\
OCS Gospels & 554 & 10 & $1.8 \%$ \\
Suprasliensis & 632 & $59-62$ & $9.3-9.8 \%$ \\
\hline
\end{tabular}

TABLE 1: Proportion of co-referentials to total dative absolutes in canonical texts.

Nevertheless, co-referential dative absolutes are attested even in the earliest texts, not just in later instances, as Bauer claims; there is no written evidence for a stage of Slavic without the possibility of co-reference. As shown in Table 1, coreferential dative absolutes constitute $5.8 \%-6.1 \%$ of the total number of dative absolutes in the Old Church Slavonic canon. ${ }^{12}$ Admittedly, there are relatively few $(1.8 \%$ of the total) in the Gospels, late tenth- and early eleventh-century manuscripts whose protographs are thought to have been translated by the bilingual Byzantine Constantine-Cyril in the 860s with supplements for the tetraevangelion by his brother Methodius prior to 885 . However, the rate of co-referentiality is $9.3-9.8 \%$ in the longest of the Old Church Slavonic texts, Codex Suprasliensis, an eleventhcentury miscellany whose protograph was presumably compiled by native Slavic translators in Bulgaria in the early tenth century (see T. Slavova in Petkanova 2003, 500).

Some scholars have cited the higher percentage of co-referential dative absolutes in Suprasliensis as evidence that they represent an innovative type, or even as a symptom of the "decadence" of the dative absolute construction as a whole. While there is a gap of two or three generations between the protographs of the Gospels and Suprasliensis, it is far from clear that the difference in the number of coreferential absolutes is due to a syntactic reanalysis occurring in the interval. There are many more and more varied contexts for absolutes (co-referential or otherwise) in Suprasliensis than in the Gospels; in addition, the patristic and Byzantine texts in Suprasliensis tend to be far more complex stylistically than the Gospels, where the majority of examples of co-referentials occur in the most elaborate book, Luke (see Collins 2004, 166). We should also take into account that the focus of Slavonic literary activity had moved from the Byzantine bilinguals of the Moravian Mission to native Slavic translators of the Kingdom of Bulgaria. Arguably, one could ascribe the increase in the co-referential type in tenth-century translations to growing nativization, of assimilation to a Slavophone milieu.

If we look at works composed during the initial periods of slavic literacy that are

[12] The total number of absolutes in the Old Church Slavonic Gospels and Suprasliensis is taken from Stanislav (1933-1934, 13, 88-90). 


\begin{tabular}{lccc}
\hline & Absolutes & Coreferentials & \% Total \\
\hline Life of Methodius and Encomium & 17 & 3 & $17.6 \%$ \\
Izbornik of 1076 & 65 & 15 & $23.1 \%$ \\
Sinai Patericon (first 100 folia) & 170 & 47 & $27.6 \%$ \\
\hline
\end{tabular}

TABLE 2: Proportion of co-referentials to total dative absolutes in non-canonical texts.

attested outside the Old Church Slavonic canon, ${ }^{13}$ we find further evidence for the early occurrence of co-referential dative absolutes. As shown in Table 2, three out of 17 absolutes (slightly less than one in five) has the same subject as the clause to which it is most closely linked semantically in the Extended Life of Methodius and the Encomium to Ss. Cyril and Methodius, original Slavic texts probably composed by one of Methodius' Slavic disciples after his death in $885 .^{14}$ Two of four dative absolutes are co-referential in About the Letters, a short apology for Slavic literacy thought to have been composed in Bulgaria in the late ninth century. ${ }^{15}$ The proportion is nearly one in four in the Izbornik of 1076, an Old East Slavic miscellany of patristic and Byzantine readings whose protograph dates to the reign of the Bulgarian Tsar Simeon (893-927), and more than one in four (counting one ambiguous case as non-co-referential) in the first 100 folia of the Sinai Patericon, a translation of John Moschus' Leimon pneumatikos thought to have been made in the late ninth or early tenth century. ${ }^{16}$ This is quite similar to the proportion in an original old East Slavic text composed more than a century later, the Primary Chronicle (Povest' vremennyx let); there, as attested in its oldest copy (the Laurentian Codex of 1377), coreferentials constitute 72 of the 282 dative absolutes, or $25.5 \%$ of the total (L. Grave, cited in Vorob'ev 1973, 92). ${ }^{17}$ On the other hand, there is a smaller proportion in the thirteenth-fifteenth-century Serbian Church Slavonic texts examined by Grković-Major $(2007,242,248)$, where $13.6 \%$ of the absolutes involving present active participles and $13.7 \%$ of those involving past active participles feature subjects co-referential with the semantic main clause.

[13] The generally accepted definition of old Church Slavonic is based on a phonological criterion-the predominance of nasal vowel letters where the corresponding nasal vowels are etymologically expected.

[14] See M. Jonova and V. Velinova in Petkanova $(2003,387-88,413)$. These texts are first attested in the Old East Slavic Uspenskij Sbornik of the late twelfth or early thirteenth century (fol. 109c-118d; Kotkov 1971, 198-212, 198-212).

[15] See D. Petkanova in Petkanova $(2003,556)$. For a reconstruction of the text based on collation of a large number of later witnesses, see Veder (1999). The two co-referential absolutes occur at 5:3 and 5:4 in Veder's reconstruction $(1999,104-105)$.

[16] See S. Nikolova in Petkanova $(2003,354)$. The Sinai Patericon is first attested in an eleventh-century old East Slavic manuscript (Golyšenko \& Dubrovina 1967).

[17] The Primary Chronicle was compiled in its final form in the early twelfth century by the Kievan monk Nestor, based in part on texts composed in the eleventh century. 
Whether or not the use of same-subject dative absolutes reflects a change in progress, there is a synchronic explanation for their distribution in Early slavic. As I have shown in previous research (Collins 2004), the seeming violations reflect a discourse principle of subject discontinuity, which can be realized by various factors, sometimes apparently working in conspiracy. The principle is an extension of the pattern seen in the "canonical" type of dative absolute, in which the two subjects are entirely discontinuous in that they have different referents. As I have covered the topic in detail elsewhere, I will treat it relatively briefly here.

Subject discontinuity can be seen as a factor in cases in which the absolute clause is distanced or stranded from the finite clause to which it is oriented. The presence of intervening phrases or clauses weakens the cohesion between the coreferential subjects and so promotes the choice of the dative absolute rather than a free adjunct (agreeing) participle. ${ }^{18}$ This can be seen clearly in example (1). ${ }^{19}$

(1) i priimŭ b[ogo]ljubivyi c[a]rŭ donesǔšę kńigy. samomou sǫ̌tou koup'no sŭ s[vę]tyimŭ sŭboromŭ. vĭ nikajeonǐstěěmŭ gradě vüfinijě. na x[rist]oborǐca arija. blagodarivŭ b[og]a. vizzěsti že i kŭ s[vę]tououmou sǔboru. jaže otŭ

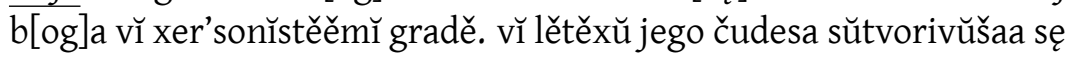
'And, the God-loving emperor ${ }_{[\mathrm{NOM}-\mathrm{SG}]}$ having $\operatorname{received}_{[\mathrm{PAP}-\mathrm{NOM}-\mathrm{SG}]}$ those who had brought the writings-[he] himself $\left[\right.$ [DAT-SG] was ${ }_{\text {[PRAP-DAT-SG] }}$ together with the Holy Council against the heretic Arius in the Nicaean city of Bithynia-having given thanks ${ }_{[\mathrm{PAP}-\mathrm{NOM}-\mathrm{SG}]}$ to God, informed ${ }_{[\mathrm{AOR}-3 \mathrm{SG}]}$ the Holy Council of the miracles that had been done by God in the city of Chersonesus in his times.' (Suprasliensis 541: 25-542: 1; Zaimov \& Capaldo 1982-1983, vol. 2, 543, 545)

In (1), 'emperor' is the referent of all three of the participial clauses that precede the finite aorist v̌zvěsti; however, the second of the three clauses is a dative absolute (which effectively makes the first a nominative absolute). The absolute is separated from the finite clause by another participial clause ("having given thanks to God"), as well as by a string of three prepositional phrases ("together with the Holy Council against the heretic Arius in the Nicaean city Bithynia"). A further possible distancing factor is the appearance of a comitative phrase after the verb 'be' within the dative absolute ("together with the Holy Council"), which introduces additional potential subjects into the discourse.

Subject discontinuity can also be a factor when the subject of the absolute clause plays a different semantic role than the co-referring subject in the finite clause.

[18] Similarly, Hoff $(1989,415)$ identifies intervening clauses as one of the factors found in co-referential ablative absolutes in Latin.

[19] The following abbreviations are used in the glosses in the English translation: AOR = aorist; $\mathrm{DAT}=$ dative; GEN = genitive; IMPERF = imperfect; INF = infinitive; NOM = nominative; $\mathrm{PAP}$ = past active participle; $\mathrm{PL}$ = plural; $\mathrm{PPP}$ = past passive participle; PRAP = present active participle; $\mathrm{SG}=$ singular. 
Generally, this involves a change in the degree of agency, as in (2). ${ }^{20}$

(2) šestǐ voinŭ piōnija nošaaxo strŭmoglavĭ. ne mogǫštemŭ že imŭ jego drǔžati. kolěnoma tŭkaaxo po rebromŭ.

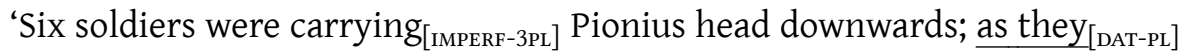
were not able ${ }_{\text {[PRAP-DAT-PI] }}$ to hold him, they pushed ${ }_{\text {[IMPERF-3PI] }}$ him in the ribs with their knees.' (Suprasliensis 137:16-19; Zaimov \& Capaldo 1982-1983, vol. $1,293)$

Here the Church Slavonic translation involves a reinterpretation of a Greek accusa-

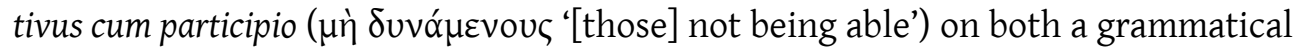
and a semantic level (3).

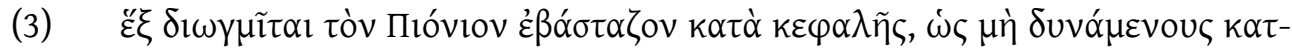

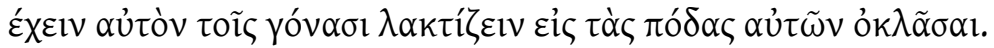

'Six cavalrymen carried Pionius head downwards, so that those not able to hold him were able to kick [him] with their knees so that he would fall to their feet. ${ }^{21}$

In the Greek text, the referent of the participial subject is not 'six calvarymen' ( $\check{\xi} \xi \delta\left(\omega \gamma \mu i \tau \alpha_{l}\right)$ but other, unnamed subjects; in the Slavonic version, the addition of the anaphoric pronoun imŭ 'they ${ }_{[\mathrm{DAT}]}$ ' suggests identity with the previous subject, 'six soldiers' (šestĭ voinŭ). The agency of these referents decreases from the first, finite clause ("were carrying") to the second, absolute clause ("were unable"). The presence of an intervening clausal element, the embedded infinitive drŭžati 'to hold', may also contribute to the discontinuity, in accordance with the pattern noted above.

The same factor can be seen at work in (4a), in which the dative absolutes are translations of Greek $\dot{\varepsilon} v \tau \tilde{\varphi}+$ infinitive constructions (4b). ${ }^{22}$

(4) a. i vŭzvrativǔši mi sę. i idø̨šti vŭ manastirŭ. omrǐkoxŭ na městě semŭ.

'And, when $\mathrm{I}_{[\mathrm{DAT}}$ turned back ${ }_{[\mathrm{PAP}-\mathrm{DAT}-\mathrm{SG}]}$ and was going ${ }_{\text {[PRAP-DAT-SG] }}$ to the monastery, [I] was benighted ${ }_{[\mathrm{AOR}-1 \mathrm{sG}]}$ in this place.' (Suprasliensis 515: 27-29; Zaimov \& Capaldo 1982-1983, vol. 2, 515).

[20] Cf. the example quoted in Collins (2004, 173), where a co-referential dative absolute clause translates an

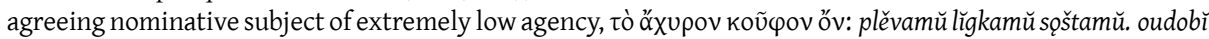
větromŭ otŭnosętŭ sę. "The chaff being light, it is easily carried off by the wind" (Suprasliensis 127:25-27; Zaimov \& Capaldo 1982-1983, vol. 1, 273.

[21] I am grateful to Brian Joseph for his help in translating this passage.

[22] This is a frequent translation equivalence (Stanislav 1933-1934,13-14). In some previous studies, it has been suggested that the Slavic translators mechanically used the dative absolute in translating $\dot{\varepsilon} v \tau \tilde{\omega}+$ infinitive, so that the appearance of co-referential absolutes was due to slavish imitation. However, it should noted that the dative absolute is actually a felicitous translation of the Greek construction, which generally has temporal meaning. 


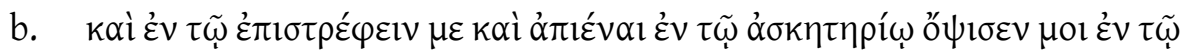

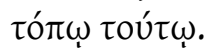

'And when I turned back and set out for the monastery, I was benighted in this place.'

In (4a), the Slavonic translation opts for the personal verb omrikoxŭ in the finite clause, even though impersonal constructions were available to render Greek

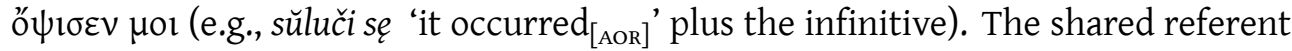
of the three conjoined subject serves as the agent of motion in the two participial phrases, but an experiencer (and a fairly helpless one, to boot) in the finite clause.

The operation of the subject discontinuity principle suggests that the purported switch-reference condition is not a syntactic rule but rather a statistically prevalent tendency influenced by discourse-pragmatic factors of cohesion and topic continuity. There would seem to be no reason for the tradition that co-referential absolutes are grammatically incorrect, apart from the imported expectation that grammatically correct absolutes should have different subjects than the main clause, which led to the circular conclusion that the scribes who used co-referential absolutes did so in error. One suspects that the switch-reference condition would not have been formulated as a hard-and-fast rule if the Early Slavic dative absolute had been described without preconceptions derived from the (supposed) behavior of absolutes in other Indo-European languages-in particular, Greek and Latin. ${ }^{23}$

The notion that dative absolutes and free adjunct participles should be in complementary distribution syntactically seems to be based on the assumption that they have the same essential function; however, this is not the case. Unlike agreeing participles, ${ }^{24}$ absolutes involve a subject that can be viewed as a separate topic

[23] The prescription on co-reference has quite an ancient tradition in grammars of the classical languages. According to Sluiter $(2000,391)$, the idea was first formulated in the Institutiones of the Latin grammarian Priscian (ca. 500), who defined the absolute construction as "an ablative of one noun and a participle... combined with a verb and a nominative of a different noun, with transition... of persons [cum transitione personarum]." Despite this prescription, there is no evidence that the co-referential type would have broken Priscian's head; the grammarian himself cited, without demur, an absolute that exemplified subject co-reference rather than "transition of persons" (ibid.; for the example, see ibid., 391-92, note 17). The eleventh-century scholar Alberic of Montecassino, the inventor of the term absolutus, made the co-reference constraint even more stringent by insisting that the subject of the absolute could not be congruent with any main-clause constituent (ibid., 394).

[24] This does not preclude agreeing participles with explicit subjects-so-called nominative absolutes, which have likewise been treated as irregular constructions; cf. Večerka $(1996,185-86)$. While these require separate study, they may be elaborations of left-shifted topics, when they are not the result of stranding, as in example (1), above. It cannot be assumed that they express the same syntactic relations as dative absolutes, as claimed by Večerka (ibid., 190). For example, nominative absolutes tend to occur in titles (prayer rubrics) in the Old Church Slavonic Euchologium Sinaiticum: mol[itva] na voisko idešte trapezo 'a prayer [as men are] going $_{\text {[PRAP-NOM-PI] }}$ to war' (19a1; Nahtigal 1942, 42). For similar examples, see ibid., 37 (17a1), 85 (37a21) and, from a different euchologium, ibid., 341. 
in the discourse (Hoff 1989, 408; König \& van der Auwera 1990, 340). ${ }^{25}$ This makes them a viable strategy when there is any form of discontinuity between two clauses that can disrupt interclausal cohesion. This may explain why dative absolutes (as well as agreeing participial clauses) are often conjoined to the adjacent clauses with coordinating conjunctions, i.e., explicit cohesive devices, as in (4a), above-a phenomenon that has often been treated as a further irregularity in the construction. ${ }^{26}$

\section{[4] SYNTACTICALLY INDEPENDENT DATIVE ABSOLUTES}

Examining co-referential dative absolutes in the Old Church Slavonic Gospels, Nečásek $(1957,25)$ suggests that they may actually be syntactically independent (nonsubordinated) units ("coordinated main clauses, abbreviated by dative absolutes"). Gebert $(1987,568)$ notes that participials, including absolutes, that are "coordinated with a principal verb" have sometimes been analyzed as independent verbs. Other scholars have noted apparently independent cases in texts attested outside of the old Church Slavonic canon. ${ }^{27}$ In some studies, these non-subordinated absolutes are viewed as post-Old Church Slavonic innovations; for example, Remneva (1989, $34,40)$ argues that the use of the dative absolute as a "simple sentence" was "its most distinctive East Slavic feature." However, there are two problems with this claim. First, it ignores the fact that apparently independent cases are also found outside the East Slavic area, in the South Slavic recensions. Second, it does not account for the presence of independent dative absolutes in Old East Slavic texts copied from tenth-century Bulgarian originals, that is, from texts composed during the Old Church Slavonic period.

Identifying a given absolute construction as non-subordinated raises a methodological problem. As Worth $(1994,30)$ rightly notes of complex dative absolutes in Old East Slavic chronicles, "the greater the number of predications, and the more complex these predications are, the less easily they are interpreted as all equally backgrounded to some single subsequent finite clause..." At the same time, in connected discourse, adjacent or nearby clauses are likely to have semantic relations, possibly made explicit by cohesive devices; these can be interpreted as a form of

[25] Occasionally, one can find absolutes with null subjects that can be recovered from the previous context, i.e., reflect the zero anaphora that is typical in cases of topic continuity; see, for example, Sinajskij Paterik 14r2-6, 18v8, and perhaps also 47r17 and 88v9 (Golyšenko \& Dubrovina 1967, 63, 72, 129, 212). In these cases, there is generally some disruption in topic continuity between the absolute and the following clause.

[26] On conjoined dative absolutes, see Večerka (1961, 50-51), Alekseev (1987), Gebert (1987, 568), Remneva $(1989,35,39)$, Corin $(1995,262-64,274-76$, "lack of conjunction" is a "canonical" constraint, ibid., 279). According to Corin $(1995,264)$, "circumstances in OCS, together with the typological facts of the modern Slavic languages, thus justify our positing a general rule that the DA was not introduced by conjunctions, either subordinating or coordinating." It is unclear what the "circumstances in OCS" are in this instance, and projecting "the typological facts of the modern Slavic languages" backwards nine or ten centuries is surely a dubious procedure.

[27] See Corin (1995, 279-80) on Old East Slavic and Grković-Major (2007, 242-43, 248-49) on Serbian Church Slavonic. 
dependency. This can be seen in (5), an excerpt from the scribe's colophon to the Ostomir Gospel (1056-57), the oldest dated Slavic text, which is written in the East Slavic recension. ${ }^{28}$

(5) napisaxŭ že eü[an]g[e]lie se. rabou b[o]žiju narečenou sǫštou vŭ kr[ॅ] štenii iosifŭ. a mirĭsky ostromirŭ. blizokou sǫštou izęslavou kŭnęzou. izęslavou že kŭnęzou togda prědrǐžęštou obě vlasti i o[ť̃]ca svoego jaroslava. i brata svoego volodimira.

'[I] wrote $_{[\text {AOR-1SG] }}$ this Gospel for God's servant ${ }_{[\mathrm{DAT}-\mathrm{SG}]}$, [who] is $_{[\mathrm{PRAP}-\mathrm{DAT}-\mathrm{SG}]}$ na$\operatorname{med}_{[\mathrm{PPP}-\mathrm{DAT}-\mathrm{SG}]}$ in baptism Iosif, but in the world Ostromir, [who] is [PRAP-DAT-SG] $_{\text {PR }}$ $\operatorname{close}_{[\mathrm{DAT}-\mathrm{sG}]}$ to Prince Izjaslav ${ }_{[\mathrm{DAT}-\mathrm{sG}]}$; Prince Izjaslav ${ }_{[\mathrm{DAT}-\mathrm{sG}]}$ at that time held [PRAP-DAT-SG] both realms-both [that] of his father Jaroslav and [that] of his brother Volodimir.' (Kirillin 1988, fol. 294b15-c3).

The italicized clause in (5) is treated as an independent absolute by Nečásek $(1957,25)$ and Remneva $(1989,34)$, neither of whom cite the preceding passage. While these scholars may be correct in claiming that izeslavou že kŭnęzou togda prědrǔžęstou obě vlasti is not subordinated, there would seem to be no principled way to prove this. Alternatively, it could be interpreted as syntactically dependent either on the preceding participial relative clause blizokou soštou izęslavou kŭnęzou or on the initial finite clause napisaxŭ že eü[an]g[e]lie se. It is certainly dependent on those clauses semantically; its function is to situate the writing of the manuscript in time (during the reign of Izjaslav) and to situate the scribe's patron, who commissioned the manuscript, in social space (as close to a prince who holds two thrones).

Such principled uncertainty is likely to exist in most coherent discourse, and especially in narrative, where the temporal ordering provides a clear superordinate structure. The sheer length and elaboration of a passage may raise the suspicion that the absolute clause it contains is functioning as an independent clause. However, this is impossible to prove objectively without knowing the scribe's tolerance for syntactic complexity; the judgment should not depend on the Sprachgefühl of the linguist.

To prove beyond reasonable doubt that a given absolute was independent, we need to look for verifiable evidence in scribal usage. In the following case-studies, I will make use of three criteria to establish the syntactic independence of the dative absolutes: 1) the presence of graphic indications that the scribe felt that the absolute construction was separate and independent; 2) the absence of another clause that could serve as a matrix on the syntactic level; and 3) discourse organization that assigns the absolute to the same or a higher level of structure than its putative matrix clause(s).

[28] For the sake of consistency, I have transliterated the graphemes $\mathbb{A}, \mathbf{x}, \ldots \times$, and $\Psi$ as ę, $Q$, jg, and št, respectively, for both Old Church Slavonic and Old East Slavic. Their phonetic values in Old East Slavic were probably [æ], [u], [(j)ü], and [šč]. 


\section{[4.1] Case-study 1: An absolute as a complete paragraph}

A dative absolute construction that is independent by the first two criteria can be found in example (6). This passage comes from the Izbornik of 1076, a collection of excerpts translated from Greek edificatory and hagiographical works attested in an Old East Slavic manuscript, which evidently reflects a Bulgarian protograph (or protographs) of the early tenth century; no Greek compilation of this kind is known (see K. Ivanova in Petkanova 2003, 211-212). The passage in question, which is quoted in its entirety here, comes from the "100 Discourses" ascribed to Gennadius of Constantinople; it is the tenth of 24 answers to the question whether it is always proper to take communion.

(6) "-Oučjaštju ny oukazaniju. jako iže sŭ nebrěženijemı̌ pričęstejutı̌ sja s[vja]tyixŭ tainaxŭ. ne tŭkmo otŭpouštenije grěxovŭ ne dajetŭ sja imŭ: nŭ i pače naskačetǐ na nja dijavolŭ. město prijemlja otŭ nixŭ nebrěženie ixŭ dělja:""IThe instruction $\left[{ }_{\text {[DAT-SG] }}\right.$ teaches [PRAP-DAT-SG] ${ }_{\text {us }}$ that those who partake of the Holy Gifts [sc. the Eucharist] with neglect, not only is remission of sins not given to them, but also the devil will attack them all the more, receiving a place from them because of their neglect. T' (Izbornik of 1076, 212r2-12).

There are multiple graphic signals in the manuscript to indicate that (6) was perceived as an independent unit of discourse. First, it is separated from both the preceding and the following answers by the kind of punctuation that generally marks a section in the Izbornik, double commas plus parágraphos (represented by pilcrows in the English translation). ${ }^{29}$ Second, its initial letter is capitalized and written in cinnabar ink, another sign of the beginning of a new section. In other words, the passage in (6) is explicitly presented as a complete textual unit comparable to a modern section or paragraph, like the 9 prior and 14 subsequent arguments in the complex of answers to the initial question. All of the arguments except (6) include non-embedded clauses with finite verbs; thus the absolute construction is treated as a parallel to finite constructions in the structure of the discourse.

Moving now to the second criterion, it can be seen that the absolute construction in (6) is not dependent on or an adjunct to any single clause either in its own paragraph or in the one preceding it; indeed, there is no "main" or "matrix" clause within the paragraph in (6) on which the initial absolute construction could depend syntactically. The introductory dative absolute oučeštju ny oukazaniju, literally "the instruction teaching us", is actually the matrix clause for the remainder of the section, the explication proper; the embedding is signalled overtly by jako 'that', the

[29] Within certain of the sections are some subsections, which are marked by non-terminal punctuation-interpunct or colon; however, one apparent subsection beginning on $21 \mathrm{r} 4$ is presented with terminal punctuation. The final answer, representing the end of the section (the answers) features heavier punctuation-a dotted obelos $(\div)$, colon, double-comma, and paragraphos $(215 \mathrm{v} 4)$. This is followed by a new question, explicitly labelled as such in cinnabar ink. 
usual complementizer for reported speech in Slavonic (see Collins 1996). ${ }^{30}$ Thus there is no basis for arguing that the absolute construction is ancillary within its own paragraph.

As an answer, (6) clearly has a semantic relation, not dependent but dyadic, with a unit in the preceding discourse, the initial question, which occurs occurs eleven pages previously (206v7-11). In addition, it has a semantic relation with the paragraph immediately preceding it, which compares those who take communion carelessly to Judas becoming possessed by the devil when he took bread sinfully at the Last Supper (Izbornik of 1076, 211v9-212r2). This New Testament reference (cf. John 13:27) is the "instruction" (oukazaniju) mentioned at the beginning of (6), so the two paragraphs are linked not only by adjacency and their common relation to the question but also by an explicit lexical cohesive device; in fact, (6) serves as an interpretation of part of the previous answer. ${ }^{31}$ Semantically, then, (6) can be construed with the section preceding it; however, its notional relation is not to any particular proposition in that section but to the paragraph in its entirety (or, at least, to the entire narrative about Judas within that paragraph). This presumably explains why it was appropriate to use an absolute construction-as a signal that the passage in (6) was perceived as ancillary in its context, an elaboration of the previous discourse.

In short, the dative absolute in (6) is presented as a graphically separate and independent unit and thus fulfills the first criterion. Moreover, it is not subordinated to any "main clause," as the standard definitions of absolute clauses would have it, but has to be construed with entire stretches of discourse; thus it fulfills the second criterion. Arguably, it may also fulfill the third criterion, if it is viewed it is as parallel and equal to the other answers in its set, which, from a modern perspective, are syntactically finite and independent.

\section{[4.2] Case-study 2: Absolutes dependent on larger-than-clause units}

The absence of a syntactic matrix -that is, the ability of absolutes to depend on units larger than the clause-is further illustrated in (7), a passage from the second-oldest dated Slavic manuscript, the Izbornik of 1073. Also known as Simeon's Miscellany, the Izbornik is an Old East Slavic copy of a Bulgarian manuscript dating from the reign of Tsar Simeon (893-927). ${ }^{32}$ In the given instance, two dative absolutes are used to introduce multiclausal stretches of reported speech (biblical quotations):

[30] The typical discourse effect of complementizing reported speech in this way (a "separate: dominant" arrangement, see Thompson 1996, 519) is to foreground the attribution. In the present case, though the use of the participle may somewhat reduce this foregrounding, the biblical authority (oukazaniju) is still presented as a salient part of the overall message.

[31] Some of the other sections marked with terminal punctuation likewise follow from the preceding text, as may be expected in a single, continuous discourse complex.

[32] This provenience is shown, inter alia, by two excerpts from an encomium to Simeon; though these were readdressed to Grand Prince Svjatoslav of Kiev, there is a scraped portion where the underlying text includes Simeon's name and title (see K. Ivanova in Petkanova 2003, 450). The compilation is believed to have been made in Bulgaria; no Byzantine anthologies of this type are known to exist (ibid.). 
(7) 187 Otŭ ap[osto]1[1̄]skyxŭ zapovědi:. Zakonopoložñikou mōüsii rekǔšo kŭ

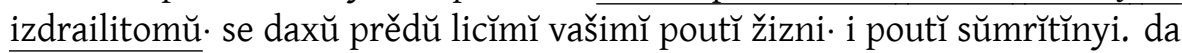
polǐz'nǫo izberi žiznı̆ da živeši i pror[o]kou ilii g[lago] jjušto $\cdot$ kŭ ljudĭmŭ. dokolě xramlete na ōboju kolěnou vašejg · ašte b[og]ŭ jest' i g[ospod] vŭslědŭ jego vŭ podobou g[lago]laše g[ospod] i i[su]sŭ nik'to že ne može dvěma g[ospodo]ma robotati. ili bo jedinogo vŭznevidi a drougago vŭzljubi.

' 187 From the Commandments of the Apostles. The law-giver Moses [Dat-sG] $\underline{\text { said }}_{[\text {PPp-DAT-SG] }}$ to the Israelites, "Lo, I set you the path of life before your face, and the path of death; choose a useful life that you may live." And the prophet Elijah $_{\text {[DAT-SG] Says }}$ [PRAP-DAT-SG] $_{\text {to the people, "How long will you limp on both }}$ knees? If God is the Lord, walk in His path." Similarly, the Lord Jesus [Nom-sc] said $_{\text {[MPERF-3SG] }}$, "No one can serve two masters; for he will hate one and love the other..." (Izbornik of 1073, 93b15-c5).

This passage is the beginning of a new reading in the miscellany; it has its own title Otŭ ap[osto]l[̌̃]skyxŭ zapovédi "From the Commandments of the Apostles"), as well as a section number (187) and large initial letter $Z$ (the beginning of the reading proper) in cinnabar ink in the margin. The reading that precedes it deals with another topic and is explicitly taken from a different source, John Climacus' The Ladder of Divine Ascent. Thus there is no preceding main clause on which the two dative absolutes could depend syntactically, nor is there any preceding discourse on which they could depend semantically. ${ }^{33}$

Likewise, the discourse following (7) does not seem to contain any "main clauses" to which the two absolutes could be syntactically subordinated. The clauses that come directly after the absolutes belong to non-embedded (non-complementized) passages of direct speech; these function as package deals, inset units of discourse, which are framed in their entirety by the participial constructions. Thus the absolutes cannot be said to depend syntactically or semantically on any particular "main clauses" or other elements within the reported speech.

If we look at the larger discourse structure, we see that the two absolutes in (7) are part of a series of three coordinated clauses introducing reported speech (biblical quotations). The final member of this series (vŭ podobou g[lago]laše g[ospod]

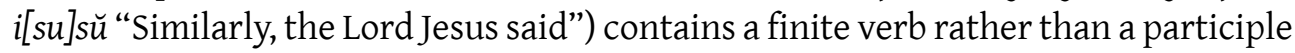
and is presented as a semantic parallel to the previous two by means of the adverbial vŭ podobou 'similarly'. If we took the stand that the absolutes must depend on a main clause, we would be forced to treat this finite clause as their head, as there is no other candidate in their vicinity. However, it is difficult to establish a relevant semantic link between the three introductory clauses ' $\mathrm{X}$ having said “...", and

[33] The title Otŭ ap[osto]l[ü]skyxŭ zapovědi "From the commandments of the Apostles," a stand-alone prepositional phrase, is on a different (meta)level in the discourse and thus cannot serve as the syntactic or semantic host of the absolute constructions. 
Y saying “...”, Z said “...”; the real connection lies in the message of the inset quotations that they introduce. Moreover, the organization of the discourse suggests that all three members of the series have identical functions-to introduce thematically similar biblical texts that will lend authority to the subsequent passage, which contains instructions on how one should behave. In other words, the three highlighted clauses are functionally equal in the discourse organization, despite their use of different kinds of predicates; they all provide support for the hortatory passage that follows, like the biblical passages that are read before a church homily. ${ }^{34}$ Thus, if the absolutes are to be construed with (regarded as dependent on) any element in the text, it is to the entire discourse that follows them discontinously, rather than to any specific syntactic unit in their immediate co-text.

\section{[4.3] Case-study 3: Absolutes as preambles to questions}

In question-and-answer passages, absolutes that are syntactically independent-i.e., have to be construed with units larger than a clause-are commonly used to introduce biblical passages or other authoritative statements that serve as preambles for questions. This is illustrated in (8), a numbered entry in a synaxarion (table of contents) found in the Izbornik of $1073 .{ }^{35}$ I have added subscript numbers in the translation to disambiguate the three third-person referents in this passage.

$\because \because \because$

105 Afanasijevo g[ospod]ou g[lago]ljuštǫ. kŭ s[vę]tyimŭ svoimŭ. jeliko že ašte i sǔvęžete boudetǐ sǔvęzano. ašte k’to razgněvajetř mouža s[vę]ta. ti da posŭletǐjazou ili běsŭ ili sŭmı̌rtř. ili ino kako tomlenije. vŭ domŭ jego može li si č[e]1[o]v[ě]kŭ tŭi moliti inogo s[vę]t[aje]go ouběžati otǔvěta s[vę]t[aje]go togo mouža $\because$

Otŭvětŭ $\because \because \because \because$

'TIII

105 Athanasius' [discourse]: the Lord ${ }_{\text {[DAT-SG] }}$ saying ${ }_{[\mathrm{PRAP}-\mathrm{DAT}-\mathrm{SG}]}$ to his holy ones, "However much you bind will be bound," if someone ${ }_{1}$ angers a holy $\operatorname{man}_{2}$, so that he $e_{2}$ sends a disease or demon or death or some other torment to his ${ }_{1}$ house, can that $\operatorname{man}_{1}$ beseech another holy one ${ }_{3}$ to escape the sentence of that holy $\operatorname{man}_{2}$ ?⿻

Answer IIII' (Izbornik of 1073, 125b29-c14)

This passage, like examples (6) and (7), is demarcated graphically as an independent unit. Like the other entries in the synaxarion of the Izbornik, it is singled out by a text number (105) and initial letter (the $A$ of Afanasijevo) written in cinnabar

\footnotetext{
[34] The fact that the third clause contains a finite verb does not necessarily imply that it is more salient in the discourse than the participial constructions; the verb is imperfective in aspect and imperfect in tense-categories that are associated with backgrounding functions.

[35] Similar examples can be found in the same manuscript at 124c27-d1, 125a9, 125c16, and 125d1.
} 
ink in the left margin. It follows and ends with major boundary punctuation-three diamond colons (signified by pilcrows in the translation). The synaxarion entry consists of the entire question followed by lighter boundary punctuation-a single diamond colon-plus the lone word Otǔvětŭ ("Answer").

In addition to being graphically separate, example (8) is independent of the entries surrounding it both syntactically and semantically. In the structure of the synaxarion, each entry is a parallel item in a set subsumed under a category at a higher level of discourse, much like the units in a modern table of contents or unnumbered bullet-list. Thus the passage in (8) constitutes an entire text, which is semantically complete within the parameters of the synaxarion genre.

The dative absolute g[ospod]ou g[lago]ljušto "the Lord saying" in (8) introduces two clauses of reported speech (a quotation from Matthew 16:19); this is followed by a conditional construction serving as the protasis of a question. Though the function of the reported-speech construction is to provide background information for the question, there is no direct semantic link between the two units; the New Testament quotation serves as a presupposition, an axiom against which the problem is set. In order to connect the quotation and the question, one has to go through a complex process of inferencing:

(i) the Lord gave the Power of Binding (excommunicating) and Loosing (restoring to communion) to His Apostles;

(ii) present-day clerics have inherited this power through the Apostolic Succession;

(iii) if there are two clerics, both ordained in the Apostolic Succession, both have inherited the Power of Binding and Loosing;

(iv) these are the presuppositions for the question: if I am "bound" (excommunicated) by one cleric with this power, can I be "loosed" (restored to communion) by another cleric with the same power?

The main cohesive device in (8) is lexical-the recurrence of the adjective 'holy', which occurs in the absolute clause and then repeatedly in the question, though with different referents. The content of the reported speech introduced by the dative absolute "feeds" or relates to each of the clauses in the question; the key to understanding the whole is to apply that content to all of the "holy ones" mentioned. However, despite these semantic links, there is no clear syntactic connection between the absolute and any single clause in the complex question; forcing such a connection actually distorts the discourse structure, in which relevant information-the absolute plus reported speech-must be related to (construed with) the entire subsequent co-text. 


\section{[4.4] Case-study 4: A dative absolute in metadiscourse}

A further instance of a dative absolute that cannot be clearly linked to a matrix clause appears in the exegetical passage in (9). In this excerpt from the Izbornik of 1073, a passage from the Book of Proverbs (30:18-19) is interspersed with terse Christological interpretations, one of which is an apparently independent dative absolute.

(9) troje jestř nemošťno mi razouměti a četvora ne razoumějo · slěda orĭlou lětęštou xristosovo vŭšstijije $\cdot$ i potii [sic] zmiinŭ po kameni dijavolŭ $\cdot$ ne obrěte bo slěda grěxovinnaago na tělesi x[ri]s[to]vě. i pouti lodija po vodě plovoušti. crikŭvi aky vŭ poučině žitrija sego naděždejo jaže vŭ x[ri]s[t]a kr[e]s[t]ĭmŭ pravimě i poutii moužę vŭ jǫnosti. roždenaago otŭ svętaago d[ou]xa. i otŭ $\mathrm{d}[\mathrm{e}] \mathrm{v}[\mathrm{i}] \mathrm{ca}$.

'Three things it is impossible for me to understand, and a fourth $\mathrm{h}_{[\mathrm{GeN}-\mathrm{SG}]}$ I do

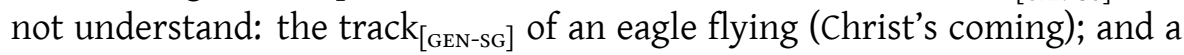
serpent's paths $_{[\mathrm{GEN}-\mathrm{PL}]}$ over a rock (the Devil ${ }_{[\mathrm{NOM}-\mathrm{SG}]}$; for he did not find a trace

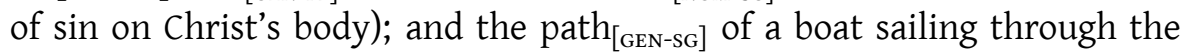
water (like the Church $_{[\mathrm{DAT}-\mathrm{SG}]}$ being governed $\left.{ }_{\text {[PAP-DAT-SG]}}\right]_{\text {in the gulf of this life }}$ by hope in Christ, by the Cross); and the paths of a man $\mathrm{n}_{\text {[GeN-PI] }}$ in youth (the One ${ }_{[\mathrm{GEN}-\mathrm{sG}]}$ born of the Holy Spirit and the Virgin).' (Izbornik of 1073, 156c1-20)

In texts like the thirteenth-century Bulgarian Church Slavonic Bologna Psalter (Dujčev 1968), commentary of the kind given in parentheses in (9) is written in a separate column, parallel with the main text, so that it is more transparently independent. In (9), by contrast, the interpretations are interpersed in and written continuously with the main text, with only interpuncts as separators. Thus the first criterion for establishing independence, graphic separateness, does not apply in this example.

In the exegetical genre, the interpolated commentary does not always occur in the form of finite clauses, but that does not imply that they consist of sentence fragments. Rather, the genre has its own specialized syntax, which allows not only finite sentences but also non-finite clauses and independent noun phrases-parentheticals that function like glosses or like the captions on pictures (which, to paraphrase Charles Sanders Peirce, are complete sentences, "but in a different language"). ${ }^{36}$ Thus, in (9), the first three interpretations in are not grammatically integrated with the biblical text. The first two are noun phrases in the nominative, the second of which is elaborated by a finite clause, like a left-dislocated topic; their counterparts in the biblical passages are noun phrases in the genitive (direct objects under negation). It would be a misunderstanding of the genre to treat this mismatch as anacoluthon, since the interpolated comments are not part of the same sentence as the biblical text.

[36] My source for this quotation is Henning Andersen (personal communication). 
The third interpretation in (9) consists of a dative absolute clause introduced by the comparative conjunction aky 'as, like'. ${ }^{37}$ The subject of the absolute is the noun crikŭvi 'church', which is preposed as a topic parallel to the nominative nouns in the first two interpretations; the entire participial phrase is grammatically independent from the explicated clause. (If there were a matrix for the comparative clause, it would have to be an equational predicate, an id est-* This is like the church being governed...- which would be predictable from the discourse structure of the genre.) Even if the dative absolute were treated as an appositive to the item that it explicates, pouti lodija po vodè plovoušti "the paths of a boat sailing through the water," it would still not be grammatically integrated, since it would parallel a genitive object; moreover, it be subordinated to a noun phrase rather than a clause. Such an analysis would miss the point that the exegetical comments in (9) are syntactic parentheticals functioning as metadiscourse rather than as part of the basic text. ${ }^{38}$

\section{[4.5] Case-study 5: Nominative absolutes in metadiscourse}

Metadiscourse in Early Slavic texts can also appear in the form of nominative absolute participial constructions, which can also be syntactically independent. As seen in (10), from the eleventh-century Old Church Slavonic Euchologium Sinaiticum, independent participles of this kind refer to a higher level of discourse-the speech event in which a hypothetical text is to be performed. ${ }^{39}$

g[ospod]ju pom[olim sę] $/$ o rabou b[o]žlju seju · imę r[ekŭ] i o x[risto]vě sŭvŭkoupleni eju .

'Let us pray to the Lord concerning these two servants of God-having said [PAP-NOM-SG] the name-and about their union in Christ.' (Euchologium Sinaiticum 9b 1-2; Nahtigal 1942, 20)

In this excerpt, the participial clause imę rekŭ 'having said the name' functions as a directive, which is indirect in that it presupposes that the desired given speech act has already been performed (hence the use of the past rather than present active participle). It is addressed to the clerics who will perform the prayer in which

[37] The grammar of the preceding clause (the biblical text) is not entirely clear. The present active participle plovoušti 'sailing' does not agree in case with lodija, the genitive singular of lodii/lodija 'boat'; it can be interpreted as an adverbialized participle (a type common in this text), a nominative absolute, or a dative singular feminine participle that should agree with lodija but has been attracted to the adjacent word vodè as the result of a perseverative error (or to the following word crikŭvi as an anticipatory error). This may have influenced the choice of a dative clause for crikŭvi 'church' in the exegetical portion, although that word is the logical counterpart of genitive 'boat' in the explicated text.

[38] The fourth interpretation, a genitive noun phrase, could in fact be interpreted as grammatically integrated with the explicated text, in apposition to the word moužz ' $\operatorname{man}_{[\mathrm{GEN}-\mathrm{SG}]}$ '. However, given the structure of the prior discourse, it is more likely to function as an independent phrase, an adnominal possessor to an

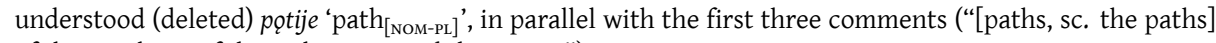
of the One born of the Holy Spirit and the Virgin").

[39] The Euchologium Sinaiticum includes ten cases of the metacomment imę rekŭ inset in prayers of various kinds (Nahtigal 1942, xxxix). 
it is inset, that is, the discourse on which is a metacomment. The function of the euchologium genre dictates that the prayers contained therein will be recited aloud during occasional rites (i.e., not during regular services). Thus the rubrics to the prayers, e.g., mol[itva] egda xotęšte vinogradŭ saditi ' $\operatorname{prayer}_{\text {[Nом-sG] }}$ when [people are] wanting [ркар-мом-тг] $_{\text {ро }}$ to plant a vineyard' (Euchologium Sinaiticum 13b19-20; ibid., 30) can be considered implicit indirect directives to the clerical readers: Say the following prayer on the specified occasion. ${ }^{40}$ The indirect command conveyed by ime rekŭ can be understood as a continuation of this same implicit speech act: Here say the beneficiary's name, and then continue the prayer. While the participial clause is clearly semantically dependent, it has no syntactic matrix clause; its proper reading depends on the hermeneutics of the euchologium genre as a whole.

A similar metatextual nominative absolute can be found in (11), a text belonging to a strikingly different register and genre-a business letter from twelfth-century Novgorod, written in the Old Novgorodian (northwestern East Slavic) dialect.

ot mě:stja:tř : ko ga:vo:ší i ko : so:di:lǐ : po:py:ta:i:ta mi : konja: a : mě:stja:ta : sja : va:ma poklanja a:že : va : čr:to : na:do:bŭ : a solita : ko monı̆ : a gramotuo : vodaita a uo pavla : skota poprosi:ta a mĭstja

'From Městjata to Gavǔša and Sŭdila. Seek out a horse for me. (And Městjata [NOM-SG] bows $_{[\mathrm{PRAP}-\mathrm{NOM}-\mathrm{SG}]}$ to you.) If you need anything, send to me. And give a letter [to my messenger], and ask money from Pavel, and Městja[ta] ${ }^{41}$ (Novgorod birchbark letter no. 422, 1140s-1150s; Zaliznjak 2004, 297)

As Gippius observes $(2004,212)$, while references to the addressees are consistently in the second person, references to the author are in the first person in the informative portions of the letter, but in the third person in the politeness formula a : městja:ta : sja : va:ma poklanja 'Městjata bowing to you' (which perhaps recurs in abbreviated form at the end of the letter). In Gippius' plausible interpretation (ibid.), this nominative absolute is metadiscourse: Městjata is telling his messenger to bow as he reads the requests in the letter to the addressees. The messenger is to perform this gesture not in his personal capacity but as Městjata's proxy-hence the third-person reference to the author.

[40] The case of the abbreviated word mol 'prayer' is, strictly speaking, ambiguous; it could also be analyzed as an accusative, that is, the direct object of the implicit verb of command: [Say this] prayer...Cf. the phrase tvore mol[i]tvo sijg 'making [PRAP-Nom-sG] this prayer ${ }_{[\text {Acc-sG] }}$ ', which follows explicit instructions on 19b12-13 (Nahtigal 1942, 44; see a similar case at 20b8-9, ibid., 47). However, in such cases of clear accusatives, there is always an explicit verb present. In other euchologia, the word 'prayer' in titles, when unaccompanied by a verbal head, is explicitly nominative, e.g., mol[i]tva céloujošte $k r[e]$ stŭ 'prayer ${ }_{[\text {Nom-sG] }}$ [when people are] kissing the Cross' (ibid., 341). Cf. also the title mol[itva] na poklonenie kolěnoma. byvajošti. vŭ s[vęttojo pętìdesętîncjo. 'prayer for the bending of knees, happening ${ }_{\text {[PRAP-NOM-SG] }}$ on Holy Pentecost', where the participle byvajošti seems to be a feminine agreeing with the nominative case (Euchologium Sinaiticum 59b15-17; ibid., 154).

[41] There has been debate over whether this letter is missing a second page (thus Zaliznjak 2004, 297) or whether the incomplete name at the end is an abbreviated closing formula (thus R. Faccani, cited in Gippius 2004, 212). 


\section{[5] DECOUPLING SEMANTIC AND SYNTACTIC DEPENDENCY}

Dative absolutes like those in (1)-(4) and (6)-(9), above, are certainly not typical or, indeed, prototypical (central) instances of the construction, but that does not imply that they were mistakes ("uncanonical"). Making a value judgment of that kind would be an exercise in covert prescriptivism, with expectations derived from inadequate descriptions and/or the contraband norms of other Indo-European languages. ${ }^{42}$ My goal in discussing such non-(proto)typical examples has been to cast doubt on the standard definition of the dative absolute as a clause that is necessarily subordinated to a matrix clause. Examples like (1)-(4) show that the noncoreference requirement is not a syntactic rule but an observation about the prototype, based not on syntax but on the same kinds of discourse tendencies that motivate overt pronominalization and other intersentential topic-continuity devices. Examples like (6)-(9) suggest that the claim that dative absolutes must have "matrix" or "main" clauses, i.e., syntactic controllers on which they are dependent, is likewise an observation about discourse tendencies rather than a syntactic rule that would be true across the board.

It might be objected that that dative absolute constructions cannot be syntactically independent because they do not include finite verbs. In fact, finiteness cannot be taken as a necessary condition for syntactic independence in Early Slavic, as is shown, inter alia, by so-called "main clause," i.e., syntactically independent, infinitives like (12a) and (12b). ${ }^{43}$ The infinitive in Slavic is in its origin a dative noun and so forms "an interesting parallel" to the dative absolute (Berent 1973, 149).

(12) a. nŭ to jemou jestř dělo ne lěniti sę nŭ g(lago)lati kŭ vॅ̌visěmŭ [sic]· a ne g[lago]lavǔšju soudŭ prijati jemou.

'But it is his business not to be idle but to speak to everyone, or else, not having spoken [PAP-DAT-SG],$\underline{\text { he }}_{[\mathrm{DAT}-\mathrm{SG}]}\left[\right.$ is] to receive ${ }_{[\mathrm{INF}]}$ judgment.' (Izbornik of 1076, 258v1-4)

b. Aže kogo ouranętĭ. poloutory grivny ser.ebra. aže bouděte bez věka: : tako platiti. ou smolěneske. i ou rizě. i na gočkomǐ berezě::

'If someone is wounded, [the penalty is] one and a half grivnas of silver, if he is left without strength. [One is] to pay ${ }_{[\mathrm{INF}]}$ thus in Smolensk and in Riga and on the Gotland Coast.' (Smolensk Treaty of 1229, Copy A, 11. 20-22; Avanesov 1963, 21)

[42] Sometimes the prescriptivism is overt rather than covert. For example, Veder $(1999,104,138)$ states that the presence of a preposed conjunction jako "mars" a dative absolute in Xrabŭr's About the Letters and that only one of the four dative absolutes there was "properly used" or "used correctly," even though his text-critical methodology indicates a ninth- or early tenth-century provenance for the given readings.

[43] This is sometimes treated (e.g., in Duridanov 1991,399) as ellipsis of 'be', but the verb 'be' is simply a copula marking tense in the given construction. Moreover, it is difficult to accept the idea of a main verb that is omitted independently of any gapping process. 
Independent infinitives can be found not only in church texts in the Slavonic register, like (12a), but also in "vernacular" texts with little or no influence from ecclesiastical syntax, like (12b), which comes from an Old East Slavic treaty. In this construction, free adjunct participles occur regularly in the dative, like ne g[lago]lavǔšju "not having spoken" in (12a), so that there is no formal distinction between agreeing and absolute adjuncts apart from the presence of explicit subjects, which, as noted above, is actually optional even for dative absolutes.

If the hypotaxis/parataxis distinction is viewed as a continuum rather than a dichotomy, dative absolutes fall closer to the pole of parataxis than more clearly subordinated clauses. It can be noted that they have most of the properties of prototypical independent clauses, including independent illocutionary force, polarity, word order, voice, and aspect (Lehmann 1988, 193-96). While dative absolutes express relative rather than independent tense relations, ${ }^{44}$ the same is true of retrospective tense-forms that are finite (perfects, pluperfects, and future perfects). Finally, like all other tensed forms in Early Slavic, the modality of dative absolutes can always be understood as indicative. (All these remarks would seem to apply to nominative absolutes as well.)

Claiming that dative absolutes can function as independent clauses is not the same as claiming that they must. In fact, as examples (13a) and (13b) show, some absolutes are explicitly dependent, in that they follow subordinating conjunctions. ${ }^{45}$ (In Early Slavic, as in the modern Slavic languages, such conjunctions usually introduce finite clauses.)

a. dońeliže na mnogy dni vŭ al' čỉě i molitvě prěbyvajoštou slavǐnououmou tomou sergju. sŭvrǔšeně vŭzmože běsŭ izgŭnati iz ńego "while that glorious Sergius $\left[\right.$ DAT-SG] remained ${ }_{\text {[PRAP-DAT-SG] }}$ for many days in hunger and prayer, [he] became completely able ${ }_{[\mathrm{AOR}-3 \mathrm{sG}]}$ to drive the demon from him.' (Suprasliensis 567: 18-20; vol. 2, 585)

b. nı̆ jako i prŭvomu suštu pismeni až . i ōt b[og]a danou rodu slověn'skomu na ōtvrŭstïe oustř . vŭ razumŭ oučeštim se boukvam . velikomı̆ razdviženïemĭ oustǐ vŭz'glasit se .

[44] Gebert $(1987,569)$ makes the relative tense of participles in absolute constructions a matter of syntactic dependency, "...le participe présent des CA manifeste toujours la valeur temporelle correspondant à celle du verbe principal tandis que le participe passé dans ces constructions indique toujours un événement précédent par rapport à celui qui est exprimé par le verbe principal." However, if absolute constructions are viewed as potentially independent clauses, it would be more accurate to say that their tense is relative not to that of a "main verb," i.e., a syntactic unit, but to the adjacent or nearby proposition to which they are semantically ancillary. In any case, relative tense in Early Slavic is not determined by syntax but by the semantics of discourse; thus verbs marked for retrospective tense (perfect, pluperfect, and future perfect) can appear in independent as well as dependent clauses.

[45] For similar cases of nominative absolutes after subordinating conjunctions, see Nahtigal (1942, 30, (13b19-20), 341). 
'But as az is both the first letter and given by God to the Slavic people to open the mouths and the understanding of those studying the letters, [it] is articulated with a great opening of the mouth...' (On the Letters; HM.SMS.463, fol. 87v8-12). ${ }^{46}$

Such explicitly subordinated dative absolutes have been viewed as late developments, part of the putative decay of the construction. ${ }^{47}$ However, as examples (13a) and (13b) show, they actually occur in the earliest texts, including some, like (13b), that are not translations from Greek. Such cases are not particularly surprising, given that absolutes can occur in some of the other syntactic environments associated with finite clauses-always provided we do not try to force the Early Slavic dative absolute into constraints characteristic of absolutes in other Indo-European languages.

Unlike examples (6)-(9) most examples of the dative absolute-those that I have called (proto)typical-can indeed be construed with an adjacent or nearby clause in such a way that they can be paraphrased as subordinate clauses (or serve as the translational equivalents of Greek subordinate clauses; see Večerka 1961, 47-48). However, given the "unruly" cases, it is important to recognize that this dependency relation is not inherently hypotactic but rather actuated on the level of discourse pragmatics. The same absolutes can equally be paraphrased paratactically, as independent clauses; their relation to the adjacent clauses is indeterminate. If there is any interclausal subordination, it is semantic rather than syntactic. Moreover, in some cases, as discussed above, the absolute is subordinated to units of discourse larger than the clause.

This is not to say that the syntactic properties of the dative absolute are irrelevant, at least if we take the view that morphological cases have inherent meaning. The combination of dative (typical for non-agent and other secondary subjects) and non-finite verbal forms is a signal to interpret the absolute clause as secondary in the discourse. ${ }^{48}$ The precise way in which it is secondary is for the most part left indeterminate. ${ }^{49}$ In narrative, the secondariness of the absolute typically signals

[46] On the Letters is thought to date to the late ninth or early tenth-century (see above). HM.SMS.463 is a fifteenth-century manuscript of the Serbian recension, Resava orthography. In this manuscript, the text of On the Letters includes traces of the Glagolitic alphabet, which suggests a Central Balkan prototype from prior to the twelfth century. I am grateful to the monks of Hilandar Monastery on Mount Athos for their permission to cite this manuscript from the microfilm held at the Hilandar Research Library of The Ohio State University.

[47] On explicitly subordinated absolutes, see Stanislav (1933-1934, 22-24), Večerka (1961, 49), Vorob'ev (1973, 93), Corin $(1995,274-76)$. Corin considers Old East Slavic cases "a qualitative difference from ocs" (ibid., 275); Remneva $(1989,39-40)$ claims that they are a post-thirteenth-century development.

[48] Such secondary status can also be signaled by the nominative case of participles and by finite verbs like the imperfect and retrospective (perfect) tenses.

[49] On the indeterminacy of absolute constructions, see Večerka (1961, 48), Berent $(1973,148,152)$, Berent (1975, 20), Gebert (1987, 566), König \& van der Auwera (1990, 337, 342), Minčeva (1991, 449), Ramat (1994, 263), Corin $(1995,261)$. 
backgrounding. ${ }^{50}$ However, there are other types of secondary status. For example, in (14), from the Old East Slavic Life of Feodosij of the Caves, probably composed in the late eleventh century, the two conjoined dative absolutes have the function of a summarizing wrap-up:

$\because$ Sicevo pr[ě]p[o]d[o]bǐnomou i prěblaženomou o[tř $]$ cju našemou feodosiju. pasouščju stado svoje. sŭ visękyimı̌ bl[a]gočšstijemı̌ i čistotoju. i ješče že i žitije svoe sŭ vŭzdǐržanijemı̆ i podvigŭmı̆ ispravljajuščju $\because \cdot$

'In this way our very holy and very blessed father Feodosij ${ }_{[\mathrm{DAT}-\mathrm{SG}]}$ shepherd$\mathrm{ed}_{[\mathrm{PRAP} \text {-DAT-SG] }}$ his flock, with every kind of piety and purity, and likewise directed ${ }_{[\text {PRAP-DAT-SG }}$ his own life with abstinence and heroism.' (Uspenskij Sbornik, late twelfth or early thirteenth century, 57d14-24; Kotkov 1971, 120)

This passage, like (6), is marked graphically as a fully separate unit of discourse, preceded and followed by major-division punctuation (diamond colons). It follows a short tale of how Abbot Feodosij's prayers prevented bandits from plundering a village owned by the monastery (ibid., 57c2-25), and it precedes a new section detailing how he dealt with an upheaval on the Kievan throne. Evidently, then, it caps off one theme (Feodosij's protection of monastic property) before the transition to the next (Feodosij's role in Kievan politics). This coda function indicates that it is semantically secondary to the previous passage, even though it is entirely independent on the syntactic level. ${ }^{51}$

\section{[6] CONCLUSIONS}

It would seem that the standard definition of the Early Slavic dative absolute as a subordinate clause is taking an observation about discourse semantics and dressing it in syntactic clothing. The Early Slavic dative absolute construction can be redefined as a clause consisting of a dative participle and, when personal, a dative subject; it has the discourse function of signaling that the proposition that it expresses is secondary in its discourse context. The relation between the absolute and the unit (in some cases, larger than a clause) to which it is most closely linked in semantic terms is not always subordination in the syntactic sense. The traditional notion that Slavic dative absolutes are subordinate clauses is evidently contraband from other Indo-European languages, perhaps influenced by the fact that typical absolutes can

[50] On absolutes as a backgrounding strategy, see Berent (1975, 11), König \& van der Auwera $(1990,337)$, Corin (1995, 259-61, 268-69).

[51] Corin (1995, 279), who cites (14) as evidence for putative syntactic differences between the old Church Slavonic and old East Slavic dative absolute constructions, rightly notes that "there is no main or matrix clause!" However, in concluding that "...under this most innovative interpretation the D[ative] A[bsolute] represents merely a stylistically marked alternative to a finite main clause, available to authors at their discretion in appropriate (presumably bookish or literary) contexts" (ibid., 280), he overlooks the secondariness of the passage in the overall discourse. 
be translated into modern languages by explicitly hypotactic clauses.

Andersen's (1970) explanation that the dative absolute reflects a Balto-Slavic dative of subordination seems to be valid both for the prehistory of the construction and for its synchronic meaning. However, it is evident that the meaning of subordination, which began in intraclausal relations, was extended (probably through syntactic reanalyses) to allow the use of datives even in syntactically independent clauses. Andersen himself presents the invariant meaning of the dative absolute in semantic rather than syntactic terms-"to present a narrated event as subordinate to another narrated event" (ibid., 8). To avoid confusion with syntactic subordination, this meaning can be termed dative of secondary status. It can be seen not only in governed datives, e.g., the secondary subjects of embedded predicates and the subjects of infinitives, but also in ungoverned dative absolutes, which are semantically secondary in ways that are left up to the intended interpreters to construe-to adjacent or nearby clauses, to entire passages of neighboring discourse, or to the infrastructure of the disourse itself.

\section{REFERENCES}

Alekseev, A. A. 1987. Participium activi v russkoj letopisi: Osobennosti funkcionirovanija. Russian linguistics 11. 187-200.

Andersen, H. 1970. The Dative of Subordination in Baltic and Slavic. In T. Magner \& W. Schmalstieg (eds.), Baltic linguistics, 1-9. University Park: Pennsylvania State University Press.

Avanesov, R. (ed.). 1963. Smolenskie gramoty XIII-XIV vekov. Moscow: Akademija Nauk SSSR.

Bauer, B. 2000. Archaic syntax in Indo-European. Berlin: Mouton de Gruyter.

Berent, G. 1973. Absolute constructions as "subordinate clauses". In C. Corum, T. Smith-Stark \& A. Weiser (eds.), You take the high node and I'll take the low node, 147-54. Chicago: Chicago Linguistics Society.

Berent, G. 1975. English absolutes in functional perspective. In R. Grossman, L. San \& T. Vance (eds.), Papers from the parasession on functionalism, 10-23. Chicago: Chicago Linguistics Society.

Coleman, R. 1989. The rise and fall of absolute constructions: A Latin case study. In G. Calboli (ed.), Subordination and other topics in Latin: Proceedings of the Third Colloquium on Latin Linguistics, 353-74. Amsterdam: John Benjamins.

Collins, D. 1996. The pragmatics of indirect speech in Old Church Slavonic and other early Slavic writings. Studies in Slavic and General Linguistics 23. 21-86. 
Collins, D. 2004. Distance, subjecthood, and the early Slavic dative absolute. ScandoSlavica 50. 165-81.

Corin, A. 1995. The dative absolute in Old Church Slavonic and Old East Slavic. Die Welt der Slaven 42. 251-84.

Dewey, T. \& Y. Syed. 2009. Case variation in Gothic absolute constructions. In J. Barðdal \& S. Chelliah (eds.), The role of semantic, pragmatic, and discourse factors in the development of case, 3-21. Amsterdam: John Benjamins.

Dujčev, I. (ed.). 1968. Bolonski psaltir: Bŭlgarsk pametnik od XIII vek. Sofija: Bŭlgarska Akademija na Naukite.

Duridanov, I. (ed.). 1991. Gramatika na starobŭlgarskija ezik. Sofija: Bŭlgarska Akademija na Naukite.

Gebert, L. 1987. Les constructions absolues en vieux russe. Revue d'études slaves 59. 565-70.

Gippius, A. 2004. K pragmatike i kommunikativnoj organizacii berestjanyx gramot. In V. Janin, A. Zaliznjak \& A. Gippius (eds.), Novgorodskie gramoty na bereste: Iz raskopok 1997-2000 godov, 183-232. Moscow: Russkie slovari.

Golyšenko, V. \& V. Dubrovina (eds.). 1967. Sinajskiij paterik. Moscow: Nauka.

Grković-Major, J. 2001. Pitanja iz staroslovenske sintakse i leksike. Novi Sad: Filozofski Fakultet.

Grković-Major, J. 2007. Spisi iz istorijske lingvistike. Novi Sad: Zoran Stojanovi.

Hoff, F.s. 1989. Les ablatifs absolus irréguliers: Un nouvel examen du problème. In G. Calboli (ed.), Subordination and other topics in Latin: Proceedings of the third colloquium on Latin linguistics, 401-23. Amsterdam: John Benjamins.

Hristova, D. 2004. Absolute constructions in Slavic: Case diversity and originality. Journal of Indo-European Studies 32. 297-317.

Kirillin, Ju. (ed.). 1988. Ostromirovo Evangelie, 1056-1057. Vol. 2: Faksimil'noe vosproizvedenie Ostromirova Evangelija. Leningrad: Avrora.

König, E. \& J. van der Auwera. 1990. Adverbial participles, gerunds and absolute constructions in the languages of Europe. In J. Bechert, G. Bernini \& C. Buridant (eds.), Toward a typology of European languages, 337-55. Berlin: Mouton de Gruyter.

Kotkov, S. (ed.). 1971. Uspenskij sbornik XII-XIII vv. Moscow: Nauka. 
Leafgren, J. 2002. The dative absolute in Middle Bulgarian texts. Zeitschrift für Slawistik 47. 147-61.

Lehmann, C. 1988. Towards a typology of clause linkage. In J. Haiman \& S. Thompson (eds.), Clause combining in grammar and discourse, 181-225. Amsterdam: John Benjamins.

Lunt, H. 2001. Old Church Slavonic grammar. 7th ed. Berlin: Mouton de Gruyter.

Minčeva, A. 1991. Datelen samostojatelen padež (dativus absolutus). In I. Duridanov (ed.), Gramatika na starobŭlgarskija ezik, 449-51. Sofija: Bŭlgarska Akademija na Naukite.

Mrazek, R. 1963. Datel'nyj padež v staroslavjanskom jazyke. In J. Kurz (ed.), Issledovanija po sintaksisu staroslavjanskogo jazyka, 225-61. Prague: Czechoslovak Academy of Sciences.

Nahtigal, R. (ed.). 1942. Euchologium Sinaiticum: Starocerkvenoslovanski glagolski spomenik. Vol 2. Ljubljana: Akademija Znanosti in Umetnosti.

Nečásek, L. 1957. Staroslověnské dativní vazby participální a jejich předlohy v řečkém textu evangelií. Slavia 26.13-30.

Nedjalkov, I. 1998. Converbs in the languages of Europe. In J. van der Auwera \& D. Ó Baoill (eds.), Adverbial constructions in the languages of Europe, 421-55. Berlin: Mouton de Gruyter.

Petkanova, D. (ed.). 2003. Starobŭlgarska literatura: Enciklopedičen rečnik. 2nd ed. Veliko Tŭrnovo: Abagar.

Ramat, P. 1994. On Latin absolute constructions. In J. Herman (ed.), Linguistic studies on Latin: Selected papers from the 6th International Colloquium on Latin Linguistics, 261-68. Amsterdam: John Benjamins.

Reiter, N. 1997. Der Dativus absolutus und sein semantischer Hintergrund. In A. Guski \& W. Kośny (eds.), Sprache-Text-Geschichte: Festschrift für Klaus-Dieter Seeman, 243-53. Munich: Otto Sagner.

Remneva, M. 1989. Konstrukcija “datel'nyj samostojatel'nyj” kak stilističeski markirovannoe sredstvo peredači vremennyx značenij. Vestnik Moskovskogo universiteta, Serija 9: Filologija 1989(2). 33-41.

Schmalstieg, W. 1982. An introduction to Old Church Slavic. 2nd ed. Columbus: Slavica.

Sluiter, Ineke. 2000. Seven grammarians on the ablative absolute. Historigraphia Linguistica 27. 379-414. 
Stanislav, J. 1933-1934. Datív absolutný v starej cirkevnej slovančine. Byzantinoslavica 5. 1-112.

Thompson, G. 1996. Voices in the text: Discourse perspectives on language reports. Applied Linguistics 17. 501-30.

Veder, W. 1999. Utrum in alterum abiturum est? A study of the beginnings of text transmission in Church Slavic. Bloomington: Slavica.

Večerka, R. 1961. Syntax aktivních participií v staroslověnštině. Prague: Statní pedagogické nakladatelství.

Večerka, R. 1996. Altkirchenslavische (Altbulgarische) Syntax. Vol. 3: Die Satztypen: Der einfache Satz. Freiburg i. Br.: Weiher.

Večerka, R. 1997. The influence of Greek on Old Church Slavonic. Byzantinoslavica 58. 363-84.

Vorob'ev, V. 1973. Datel'nyj samostojatel'nyj. Russkaja reč' 1973(4). 91-95.

Weiss, D. 1995. Russian converbs: A typological outline. In M. Haspelmath \& E. König (eds.), Converbs in cross-linguistic perspective: Structure and meaning of adverbial verb forms-adverbial participles, gerunds, 240-82. Berlin: Mouton de Gruyter.

Whaley, L. 1990. The effects of non-surface grammatical relations on the genitive absolute in Koine Greek. In K. Dziwirek, P. Farrell \& E. Mejías-Bikani (eds.), Grammatical relations: A cross-theoretical perspective, 459-71. Stanford: Center for the Study of Language and Information.

Worth, D. 1994. The dative absolute in the Primary Chronicle: Some observations. Harvard Ukrainian Studies 18. 29-46.

Zaimov, J. \& M. Capaldo (eds.). 1982-1983. Suprasŭlski ili Retkov sbornik. 2 vv. Sofija: Bŭlgarskata Akademija na Naukite.

Zaliznjak, A. 2004. Drevnenovgorodskij dialekt. 2nd ed. Moscow: Jazyki slavjanskoj kul'tury.

AUTHOR CONTACT INFORMATION

Daniel E. Collins

The Ohio State University

Department of Slavic and East European Languages and Literatures

400 Hagerty Hall

Columbus, Ohio 43210

U.S.A.

collins.232@osu.edu 